\title{
Goat scrotal-testicular biometry: Influence of the season on scrotal bipartition ${ }^{1}$
}

\begin{abstract}
Antonio A.N. Machado Júnior ${ }^{2 *}$, Antonio C. Assis Neto ${ }^{3}$, Carlos E. Ambrósio 4 , Rudolf Leiser ${ }^{5}$, Gustavo S. Lima ${ }^{6}$, Leonardo S. Oliveira ${ }^{6}$ and Maria A.M. Carvalho ${ }^{6}$

ABSTRACT.- Machado Júnior A.A.N., Assis Neto A.C., Ambrósio C.E., Leiser R., Lima G.S., Oliveira L.S. \& Carvalho M.A.M. 2011. Goat scrotal-testicular biometry: Influence of the season on scrotal bipartition. Pesquisa Veterinária Brasileira 31(12):1116-1119. Curso de Medicina Veterinária, Universidade Federal do Piauí, Campus Profa Cinobelina Elvas, Bom Jesus, PI 64900-000, Brazil. E-mail: machadojunior2@yahoo.com.br

The scrotal-testicular biometry was evaluated in goats raised in Piaui state, Brazil, presenting different levels of scrotal division, in rainy and dry periods of the year. For this study, eighteen male goats at mating age were accomplished and arranged into three groups ( 6 animals each), obeying the classification as goats with no scrotal bipartition (GI), goats showing scrotal bipartition up to $50 \%$ of testicular length (GII), and goats with more than $50 \%$ of scrotal bipartition (GIII). The biometry of the scrotal-testicular was made evaluating the scrotal length (SL), scrotal circumference (SC), testicular length (TL) and testicular volume (TV). The results were evaluated following the variance analysis (ANOVA) and the SNK test applied on the average comparisons. The analysis of the data demonstrated high values, in dry and rainy periods, of SC $(24.63 \mathrm{~cm} / 26.97 \mathrm{~cm})$, SL $(16.61 \mathrm{~cm} / 18.24 \mathrm{~cm})$, TL $(5.32 \mathrm{~cm} / 5.93 \mathrm{~cm})$, TV $\left(173.81 \mathrm{~cm}^{3} / 203.01 \mathrm{~cm}^{3}\right)$. This supports the hypothesis of the influence of the period of the year and of the scrotal bipartition on the scrotal-testicular biometry in goat.
\end{abstract}

INDEX TERMS: Goats, scrotal bipartition, biometry, year-periods variability.

RESUMO-- [Biometria escroto-testicular em caprinos: influência de período do ano na bipartição escrotal.] Objetivou-se neste trabalho avaliar a biometria escroto-testicular em caprinos com escroto simples e bipartido, criados no Estado do Piauí, Brasil, nos períodos seco e chuvoso do ano. Foram utilizados 18 caprinos machos, divididos em três grupos de seis caprinos. 0 grupo I (escroto sem bipartição), o grupo II (escroto bipartido até 50\% de comprimen-

\footnotetext{
${ }^{1}$ Received on March 3, 2011.

Accepted for publication on August 2, 2011

${ }^{2}$ Curso de Medicina Veterinária, Universidade Federal do Piauí (UFPI), Campus Professora Cinobelina Elvas, BR 135, Km 3, Bairro Planalto Horizonte, Cibrazem, Bom Jesus, PI 64900-000, Brazil. *Corresponding author: machadojunior2@yahoo.com.br / machadojunior@ufpi.edu.br

${ }^{3}$ Departamento de Cirurgia, Faculdade de Medicina Veterinária e Zootecnia, Universidade de São Paulo (USP), Av. Prof. Dr. Orlando Marques de Paiva 87, São Paulo, SP 05508-270, Brazil

${ }^{4}$ Faculdade de Zootecnia e Engenharia de Alimentos, USP, Campus Pirassununga, Av. Duque de Caxias Norte 225, Pirassununga, SP 13635-900, Brazil.

${ }^{5}$ Institut für Veterinär Anatomie, Histologie und Embryologie der Justus-Liebig-Universität Giessen, Frankfurter Strasse 98, Giessen, Germany.

${ }^{6}$ Departamento de Morfofisiologia Veterinária, UFPI, Campus Agrícola da Socopo s/n, Teresina, PI 64049-550, Brazil.
}

to testicular) e o grupo III (bipartição escrotal superior a $50 \%$ do comprimento testicular). A biometria escroto-testicular consistiu do comprimento escrotal (COE), circunferência escrotal (CE), comprimento testicular (CT) e volume testicular $(\mathrm{V})$. Os resultados foram submetidos à análise de variância (ANOVA), seguido do teste SNK para comparação das médias. Os dados mostraram que os animais do grupo GIII apresentaram, no período seco, os valores de CE, COE, CT e V de $24,63 \mathrm{~cm}, 16,61 \mathrm{~cm}, 5,32 \mathrm{~cm}$, e $173,81 \mathrm{~cm}^{3}$, respectivamente e de $26,97 \mathrm{~cm}$ para $\mathrm{CE}, 18,24 \mathrm{~cm}$ para $\mathrm{COE}$, $5,93 \mathrm{~cm}$ para CT e $203,01 \mathrm{~cm}^{3}$ para $\mathrm{V}$, no período chuvoso. Todos esses valores foram superiores $(p<0,05)$ aos encontrados para os animais dos demais grupos. Conclui-se que o grau de bipartição escrotal e o período do ano interferem na biometria escroto-testicular de caprinos.

TERMOS DE INDEXAÇÃO: Caprinos, escroto bipartido, biometria.

\section{INTRODUCTION}

Several factors induce morpho-physiological adaptations in animals, and could contribute to the modification of the reproductive efficiency. One example of this adaptation was described by Robertshaw (1982) for goats in arid and 
semiarid regions in Eastern Africa, as well as the observations describing scrotal bipartition by Numes et al. (1984) for goats in Northeastern Brazil.

This characteristic considerably increases the testis superficies exposed to the external ambience, which would make a better heat dissipation, increasing the biometrical spermatic quality, and reproductive efficiency parameters in comparison with animals which do not present this anatomical specialization (Nunes et al. 1983, Silva et al. 1986, Machado Júnior et al. 2009, Almeida et al. 2010).

Several studies with cattle (Bailey et al. 1996, 1998, Unanian et al. 2000, Pant et al. 2003), goats (Villar Filho et al. 1993, Santos \& Simplício 2000, De La Vega et al. 2001, Campos et al. 2003), and sheep (Ferreira et al. 1988, Moreira et al. 2001) demonstrated that the scrotal-testicular biometry seems to be a reliable indicator for the spermatic capacity of the animal; thus, depending on a susceptibility range of climatic factors during the year, regarding temperature and humidity among others.

Based on these factors, this study aims to evaluate the influence of scrotal morphology over the scrotal-testicular biometry in goats in different seasons of the year.

\section{MATERIALS AND METHODS}

Local habitat of experimental animals. The study was developed at an experimental goat farm located at the Agrarian Centre of the Piauí Federal University, Teresina/Piauí, Brazil, using goats without defined breed raised in Piauí. The goats were submitted to clinical evaluation, dividing them into three groups with six animals each, the first to be normal with no scrotal bipartition (GI), the second with scrotal bipartition up to $50 \%$ of testicular length (GII), and the third with more than $50 \%$ of scrotal bipartition (GIII) (Fig.1). The animals were 8 to 24 months old and had an average weight of $30 \mathrm{~kg}$.

Ambient temperature and relative humidity. During the development of the study, the ambient temperature and the relative humidity of air were measured with the aid of a digital thermal-hygrograph (Model DT8829).

Scrotal and testicular biometry. Data about the scrotal-testicular biometry were obtained, once a week for eight weeks, from October to November 2004 referring to the dry period and from February to March 2005, relating to the rainy period.
The scrotal biometry consisted in the determination of the scrotal length (SL) and scrotal circumference (SC). The scrotal length (SL) was obtained by measuring the distance between the abdominal wall and the extreme of the third distal portion of the scrotum, and the SC measuring the largest portion of the scrotal with the aid of a ruler.

The testicular length (TL) and volume (TV) were estimated: the TL by measuring the distance from the testis caput to the caudal region, not considering the epididymis, with the aid of a digital pachymeter (Cooland Proff $150 \mathrm{~mm} / 6$ "). The volume was calculated by applying the formula: $2\left[\left(\mathrm{r}^{2}\right) \times \pi \times \mathrm{h}\right]$, in which $\mathrm{r}=$ width $/ 2$, $\pi=3.14$ and $h=$ testicle length. According to the relates taken by Fields et al. (1979) and by Unanian et al. (2000), the formula described above was the most reliable when comparing results to the liquid displacement technique.

Statistical analysis. The results of the scrotal-testicular biometry were submitted to the variance analysis (ANOVA) delineate by chance in a subdivided portion scheme following the Student-Newman-Keuls (SNK) test for average comparison at $5 \%$ probability level.

\section{RESULTS}

Throughout the experiment, the data associated to the environmental temperature (ET) and the relative humidity of air $(\mathrm{RH})$ were measured and are expressed in Table 1 . In the dry period these data were $35.07 \pm 2.43^{\circ} \mathrm{C}$ and $56.09 \pm 2.3 \%$ and in the rainy period $30.29 \pm 2.26^{\circ} \mathrm{C}$ and $76.23 \pm 3.4 \%(\mathrm{p}<0.05)$.

The scrotal-testicular biometry results, referring to dry and rainy periods, are expressed in Table 2 . The group GIII presented the most expressed biometry values either for testicle and scrotal measurements: in the dry period Group III presented for SC, SL, TL and TV values of $24.63 \pm 0.80 \mathrm{~cm}$, $16.61 \pm 0.40 \mathrm{~cm}, 5.32 \pm 0.10 \mathrm{~cm}$, and $173.81 \pm 5.8 \mathrm{~cm}^{3}$ respectively, while in the rainy period, $26.97 \pm 0.76 \mathrm{~cm}$, $18.24 \pm 0.32 \mathrm{~cm}, 5.93 \pm 0.19 \mathrm{~cm}$, and $203.01 \pm 8.3 \mathrm{~cm}^{3}$ for the same parameters. These data suggest a positive-related influence of the dry and rainy period on the scrotal-testicular biometry associated by the environmental temperature and relative humidity. In group III, the data comparison between the dry and the rainy period showed a significant difference $(p<0.05)$ and a superior result in comparison with the other groups (Table 2).

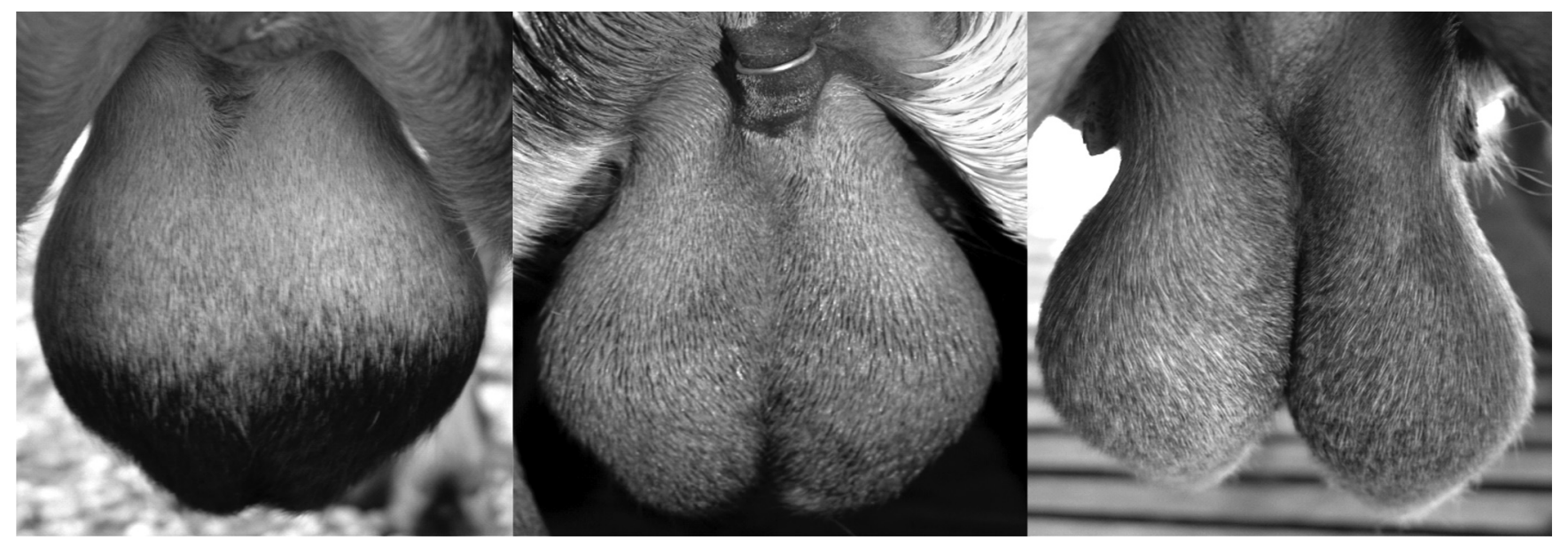

Fig.1. Scrotal region of goats in the three groups. (GI) Goats presenting no bipartition. (GII) Goats with bipartition up to 50\%. (GIII) Goats with bipartition of more than $50 \%$ of the testicular length (Machado Júnior et al. 2009). 
Table 1. Behavior of the environmental temperature (ET) and average relative humidity of air ( $\mathrm{RH})$, obtained in dry and rainy periods, Teresina/PI, Brazil

\begin{tabular}{ccc}
\hline Period & $\left.\mathrm{ET}^{\circ}{ }^{\circ} \mathrm{C}\right)$ & $\mathrm{RH}(\%)$ \\
\hline Dry & $35.07 \pm 2.43^{\circ} \mathrm{C}^{\mathrm{a}}$ & $56.09 \pm 2.3 \%{ }^{\mathrm{a}}$ \\
Rainy & $30.29 \pm 2.26^{\circ} \mathrm{C}$ & $76.23 \pm 3.4 \%$ \\
\hline${ }^{\mathrm{a}} \mathrm{p}<0.05$ in relation to the rainy period. ANOVA followed by the SNK test.
\end{tabular}

Table 2. Behavior of the scrotal circumference (SC), scrotal length (SL), testicular length (TL), and testicular volume (TV) in dry and rainy periods of year, Teresina/PI, Brazil

\begin{tabular}{ccccc}
\hline \multirow{2}{*}{ Period/Parameter* } & \multicolumn{3}{c}{ Group** $^{* *}$} \\
\cline { 3 - 5 } & & GI & GII & GIII \\
\hline \multirow{6}{*}{ Dry } & SC & $23,43 \pm 0,30$ & $22,84 \pm 0,20^{\mathrm{B}}$ & $24,63 \pm 0,80^{\mathrm{A}}$ \\
& SL & $16,00 \pm 0,10$ & $15,79 \pm 0,29$ & $16,61 \pm 0,40^{\mathrm{C}}$ \\
& TL & $5,10 \pm 0,11$ & $5,02 \pm 0,10$ & $5,32 \pm 0,10^{\mathrm{D}}$ \\
\multirow{4}{*}{ Rainy } & TV & $164,51 \pm 4,2$ & $154.69 \pm 6.3$ & $173,81 \pm 3,8^{\mathrm{E}}$ \\
& SC & $24,82 \pm 0,40$ & $25,73 \pm 0,45^{\mathrm{B}}$ & $26,97 \pm 0,76^{\mathrm{A}}$ \\
& SL & $16,78 \pm 0,15$ & $17,37 \pm 0,27$ & $18,24 \pm 0,32^{\mathrm{C}}$ \\
& TL & $5,42 \pm 0,15$ & $5,59 \pm 0,13$ & $5,93 \pm 0,19^{\mathrm{D}}$ \\
& TV & $178,67 \pm 5,2$ & $190.30 \pm 5.2$ & $203.01 \pm 8.3^{\mathrm{F}}$
\end{tabular}

* SC = Scrotal circumference $(\mathrm{cm}), \mathrm{SL}=$ scrotal length $(\mathrm{cm}), \mathrm{TL}=$ testicular length $(\mathrm{cm})$ and TV = testicular volume $\left(\mathrm{cm}^{3}\right)$.

A) $p<0.05$ in relation to SC of the groups GI and GII in the same period (dry or rainy).

B) $p<0.05$ in relation to SC of the group GI in the same period (dry or rainy);

C) $p<0.05$ in relation to the SL of the groups GI and GII in the same period (dry or rainy);

D) p $<0.05$ in relation to the TL of the groups GI and GII in the same period (dry or rainy);

E) $p<0.05$ in relation to the VT of the group GII in the dry period;

F) $p<0.05$ in relation to the VT of the group GI in the rainy period.

ANOVA followed by the SNK test.

** GI = goats without scrotal bipartition, GII = goats with bipartite scrotum up to $50 \%$ and GIII = goats with scrotal bipartition superior to $50 \%$.

In relation to Table 2, there was a significant difference $(\mathrm{p}<0.05)$ for the dry period when compared to the rainy period for all groups. Group III presented the highest results for SC in both study periods, while the analysis of GII in the dry period revealed the lowest result $(\mathrm{SC}=22.84 \pm 0.20 \mathrm{~cm}$ ); for the rainy period it was inferior only to GIII (Table 2). The comparison of SC of the goats between the dry and the rainy period demonstrated to be higher in the rainy period revealing influence of the season on the parameters.

The analysis of SL, TL, and TV (Table 2) results similar to the SC, being the rainy period significantly different $(p<0.05)$ and GIII presenting the highest values when compared among the groups.

In the dry period, group GII was the one with smallest average of TV $\left(154.69 \pm 6.3 \mathrm{~cm}^{3}\right)$, what is statistically the same as group GI $\left(164.51 \pm 4.2 \mathrm{~cm}^{3}\right)$ and different from GIII $\left(173.81 \pm 5.8 \mathrm{~cm}^{3}\right)$. Groups GI and GIII did not present statistical difference ( $p>0.05)$. In the rainy period, group GI presented the lowest average $\left(178.67 \pm 7.2 \mathrm{~cm}^{3}\right)$, being statistically similar to GII $\left(190.30 \pm 5.2 \mathrm{~cm}^{3}\right)$ and different from GIII $\left(203.01 \pm 8.3 \mathrm{~cm}^{3}\right)$. Groups GII and GIII of the rainy period did not differ between themselves ( $p>0.05$ ) (Table 2).

\section{DISCUSSION}

The results presented here, concerning the environmental temperature and the relative humidity in dry and rainy pe- riods in the region of Piaui, Brazil, reveal to be significant $(p<0.05)$. The importance of this investigation has also been based on Ferreira et al. (1988), Vilar Filho et al. (1993), Bailey et al. (1996, 1998), Santos \& Simplício (2000), Unanian et al. (2000), De La Vega et al. (2001), Moreira et al. (2001), Campos et al. (2003), Pant et al. (2003), who considered, in general, the strong influence of the year period on scrotal and testicular biometry in those animal species.

Our analysis of scrotal parameters, width and scrotal perimeter and testicular length, showed a significant difference $(p<0.05)$ between the dry and the rainy period. The goats with a high level of scrotal bipartition demonstrated higher values of scrotal perimeter and testicular length in the dry year period, an observation also made by Almeida et al. (2010). Similarly, Villar Filho et al. (1993) and Campos et al. (2003), concerning morphometrical investigation of male genital organs in dry and rainy periods, suggested an interference of season on the size of the organs, whereas Santos \& Simplício (2000) verified the scrotal and testicular response to the increased thermal stress, induced by an insulating bag positioned over the scrotum. Moreira et al. (2001) carried out a study in rams, comparable to the goat, observing that the increase on the environment temperature promoted a negative influence correlation on the scrotal circumference and testicular length. Ferreira et al. (1988) demonstrated a positive relationship between the scrotal perimeters, seminal quality and the year period, whilst high temperatures (dry period) were negatively related to.

The testicular volume showed similarly to the parameters described above. In the dry period all of the investigated groups had values inferior to those observed in the rainy period, in spite of the fact that group GIII showed a superior testicular volume in regard to the other groups in both periods (Table 2). This group GIII by the values $173.81 \pm 5.8$ and $203.01 \pm 8.3 \mathrm{~cm}^{3}$, being superior to group GI with $164.51 \pm 4.2$ and $178.67 \pm 7.2 \mathrm{~cm}^{3}$, and to GII with $154.69 \pm 6.3$ and $190.30 \pm 5.2 \mathrm{~cm}^{3}$, however they were inferior to the once described by Villar Filho et al. (1993) in Pardo Alpina, Anglo Nubiana and Canindé breeds, which presented $367 \mathrm{~cm}^{3}, 385 \mathrm{~cm}^{3}$ and $270 \mathrm{~cm}^{3}$ respectively. These differences can be explained by racial pattern and the intensive exploitation of the animals, conditions which contrast to the semi-intensive exploitation and the cross-breed animals accomplished in our study.

\section{CONCLUSION}

It can be concluded that the scrotal bipartition interferes positively on the scrotal-testicular biometry due to the increased variation of parameters influenced by climatic conditions. This was noticed at the most in the group with high level of bipartition and distinct results of scrotal-testicular biometry along the experiment.

Acknowledgements.- To Conselho Nacional de Desenvolvimento Científico e Tecnológico (CNPq) for financial support of the project MCT/CNPq/ PADCT (Proc.620145/04-8).

\section{REFERENCES}

Almeida M.M., Machado Júnio A.A.N., Ambrósio C.E., Menezes D.J.A., Righi D.A., Nascimento I.M.R. \& Carvalho M.A.M. 2010. Influência da grau de 
bipartição escrotal sobre parâmetros reprodutivos de caprinos. Pesq. Vet. Bras. 30(4):345-350.

Bailey T.L., Monke D., Hudson R.S., Wolfe D.F., Carson R.L. \& Riddel M.G. 1996. Testicular shape and its relationship to sperm production in mature Holstein bulls. Theriogenology 46:881-887.

Bailey T.L., Hudson R.S., Powe T.A., Riddell M.G., Wolfe D.F. \& Carson R.L. 1998. Caliper and ultrasonographic measurements of bovine testicles and mathematical formula for determining testicular volume and weigth in vivo. Theriogenology 49:581-94.

Campos A.C.N., Nunes J.F., Silva Filho A.H.S. \& Monteiro A.W.U. 2003. Parâmetros biométricos do trato genital masculino de caprinos sem raça definida (SRD) criados no semi-árido nordestino durante o período seco e chuvoso. Braz. J. Vet. Res. Anim. Sci. 40(3):185-189.

De La Vega A., Ruiz R. \& Wilde O.R. 2001. Relación de la circunferência escrotal com algunos parâmetros de calidad seminal em caprinos criollos de la província de Tucumán (Argentina). Zootec. Trop. 19:455-463.

Ferreira J.M.M., Silva J.F. \& Moraes J.C.F. 1988. Associação entre caracteres reprodutivos, peso corporal e época do ano e sua potencial importância na seleção de borregos Corriedale. Revta Brasil. Reprod. 12(2):69-76.

Fields M.J., Burns W.C. \& Warnick A.C. 1979. Age, season and breed effects on testicular volume and semen traits in young beef bulls. Anim. Sci. 48:1299-1304.

Machado Júnior A.A.N., Miglino M.A., Menezes D.J.A., Assis Neto A.C., Leiser R., Silva R.A.B. \& Carvalho M.A.M. 2009. Influence of the bipartite scrotum on the testicular and sacrotal temperatures in goats. Pesq. Vet. Bras. 29(10):797-802.

Moreira E.P., Moura A.A.A. \& Araújo A.A. 2001. Efeito da insulação escrotal sobre a biometria testicular e parâmetros seminais em carneiros da raça
Santa Inês criados no estado do Ceará. Revta Brasil. Zootec. 30:17041711.

Nunes J.F., Riera G.S., Silva A.E.F.D., Ponce de Leon F.A. \& Lima F.A.M. 1983. Características espermáticas de caprinos Moxotó de acordo com a morfologia escrotal. Circular Técnica 6, Embrapa-CNPC, Sobral. 11p.

Nunes J.F., Riera G.S., Silva A.E.F.D., Ponce de Leon F.A. \& Lima F.A.M. 1984. Preliminary report on observed differences in goat semen characteritics based on scrotal morphology. Proc. 20 $0^{\underline{a}}$ Reunion Internationale de Reproduction des Ruminants en Zone Tropical, Guadeloupe, 1983. INRA, Paris, p.251-264. (Les colloques de I'INRA)

Pant H.H., Sharma R.K., Patel S.H., Shukla H.R., Mittal A.K., Kasiraj R., Misra A.K. \& Prabhakar J.H. 2003. Testicular development and its relationship to semen production in Murrah buffalo bulls. Theriogenology 60:27-34.

Robertshaw D. 1982. Concepts in animal adaptation: thermoregulation of the goat. Proc. $3^{\text {rd }}$ International Conference on Goat Production and Disease, Tucson. Dairy Goat Journal, Seoltsdale, p.395-397.

Santos D.0. \& Simplício A.A. 2000. Parâmetros escroto-testiculares e de sêmen em caprinos adultos submetidos à insulação escrotal. Pesq. Agropec. Bras. 35(9):1835-1841.

Silva A.E.D.F., Nunes J.F. \& Melo F.A. 1986. Influência da morfologia escrotal nas características do sêmen e seus efeitos na fertilidade de caprinos. Hora Vet. 5(29):66-69.

Unanian M.M., Silva A.E.D.F., McManus C. \& Cardoso E.P. 2000. Características biométricas testiculares para avaliação de touros zebuínos da raça Nelore. Revta Bras.. Zootec. 29:133-144.

Villar Filho A.C., Birgel E.H., Barnabé V.H., Vinsintin J.A. \& Barnabé R.C. 1993. Características testiculares e seminais de caprinos na região semi-árida do Estado da Paraíba. I. Características Testiculares. Revta Bras. Reprod. Anim. 17(1/2):17-23. 